\title{
Autologous Hematopoietic Stem Cell Transplantation for Chronic Inflammatory Demyelinating Polyradiculoneuropathy
}

\author{
Josée Masson-Roy, Ari Breiner, Jodi Warman-Chardon, Catherine E. Pringle, \\ David Allan, Christopher Bredeson, Lothar Huebsch, Natasha Kekre, \\ Michael Lee Kennah, Lisa Martin, Sheryl McDiarmid, Sultan Altouri, \\ Harold Atkins, Pierre R. Bourque
}

\begin{abstract}
Background: Chronic inflammatory demyelinating polyradiculoneuropathy (CIDP) refractory to conventional therapy can lead to marked disability and represents a therapeutic challenge. Objective: To report five cases of treatment-refractory disabling CIDP treated with autologous hematopoietic stem cell transplantation (AHSCT). Methods: This was a retrospective cohort study from a tertiary care referral center for both neuromuscular disease and AHSCT. Patients with CIDP treated with AHSCT between 2008 and 2020 were included. All patients had major persistent and disabling neuropathic deficits despite combinations of intensive immunosuppressive therapy. The primary outcome measures were: Medical Research Council sum score, Overall Neuropathy Limitations Scale and requirement for ongoing CIDP immunotherapy after transplantation. We also analyzed safety outcomes by documenting all severe AHSCT-related complications. Results: Five patients with refractory CIDP underwent AHSCT. Three were classified as manifesting a typical syndrome, two were classified as the multifocal Lewis Sumner variant. The mean age at time of CIDP diagnosis was 33.4 years (range 24-46 years), with a median delay of 46 months (range 21-135 months) between diagnosis and AHSCT. The median follow-up period was 41 months. All five patients were able to wean off CIDP-related immunotherapy. Marked improvements in Medical Research Council scale and overall Neuropathy Limitations Scale were noted in 4/5 patients. One patient with longstanding neurogenic atrophy showed no improvement in disability scales. There were no treatment-related deaths or critical illnesses. Conclusions: AHSCT can achieve marked sustained clinical improvement of refractory CIDP and may allow for weaning off long-term complex immunotherapies.

RÉSUMÉ : Greffe autologue de cellules souches hématopoiétiques dans la polyradiculonévrite inflammatoire démyélinisante chronique. Contexte : La polyradiculonévrite inflammatoire démyélinisante chronique (PIDC) réfractaire au traitement usuel peut conduire à une incapacité importante et poser des problèmes thérapeutiques. Objectif : L'étude visait à faire état de 5 cas de PIDC rebelle et invalidante, traitée par une greffe autologue de cellules souches hématopoïétiques (GACSH). Méthode : Il s'agit d'une étude de cohortes, rétrospective, réalisée dans un centre de soins tertiaires, spécialisé dans le traitement des maladies neuromusculaires et la GACSH. Ont été inclus les patients atteints de PIDC et traités par la GACSH, entre 2008 et 2020. Tous présentaient d'importants troubles neuropathiques persistants et invalidants malgré l'association de traitements immunosuppresseurs intensifs. Les principaux critères d'évaluation comprenaient le score sur les échelles du Medical Research Council (MRC) et Overall Neuropathy Limitations Scale (ONLS) ainsi que les besoins continus d'immunothérapie dans les cas de PIDC après la greffe. Ont également été consignées toutes les complications graves liées à la GACSH aux fins d'analyse de l'innocuité. Résultats : Cinq patients ont été soumis à la GACSH pour cause d'une PIDC réfractaire : trois présentaient un syndrome considéré comme typique; deux, des troubles considérés comme une variante multifocale du syndrome de Lewis-Sumner. L'âge moyen au moment de la pose du diagnostic de PIDC était de 33,4 ans (24-46 ans), et le temps médian écoulé entre la pose du diagnostic et la GACSH, 46 mois (21-135 mois). La durée médiane du suivi a atteint 41 mois. Tous les patients, sans exception, ont pu être sevrés de l'immunothérapie liée à la PIDC. De plus, les scores sur les échelles du MRC et ONLS ont révélé une amélioration importante de l'état chez 4 patients sur 5; un seul, souffrant d'une atrophie neurogène de longue date, n'a pas connu une amélioration des résultats sur les échelles d'incapacité. Aucune maladie grave ou aucun décès n'ont été enregistrés en lien avec le traitement. Conclusion : La GACSH peut permettre par une amélioration importante et continue de l'état clinique chez les patients atteints d'une PIDC réfractaire, voire le sevrage d'une immunothérapie complexe et prolongée.
\end{abstract}

Keywords: Neuromuscular disorders, Polyneuropathy, Neuroimmunology

doi:10.1017/cjn.2021.30

Can J Neurol Sci. 2021; 48: 760-766

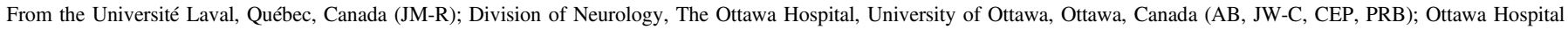

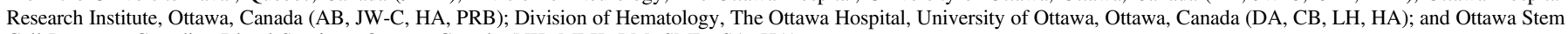
Cell Program, Canadian Blood Services, Ottawa, Canada (NK, MLK, LM, SMD, SA, HA)

Received December 30, 2020. Final Revisions Submitted February 10, 2021. Date of Acceptance February $10,2021$.

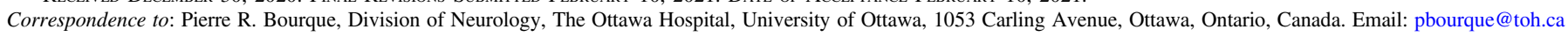




\section{INTRODUCTION}

Chronic inflammatory demyelinating polyradiculoneuropathy (CIDP) is a heterogeneous syndrome grouping patients with acquired autoimmune neuropathy presenting as acute, relapsing-remitting or more often insidiously progressive polyradiculoneuropathy. Up to $20 \%$ of patients with CIDP are refractory to proven first-line therapies (IVIG, corticosteroids, plasma exchange). ${ }^{1-3}$ Although other immunomodulatory and immunosuppressive agents (such as cyclophosphamide, fludarabine or rituximab) have been used in treatment-refractory patients, evidence for their efficacy is mostly based on small case series and none has been proven to induce lasting disease remission. 4

Autologous hematopoietic stem cell transplantation (AHSCT) has been increasingly used in the treatment of severe autoimmune neurological conditions such as multiple sclerosis and myasthenia gravis. ${ }^{5-7}$ The goal of this approach is to first eliminate the destructive aberrant immune response using a combination of chemotherapies and anti-lymphocyte antibodies. A naïve self-tolerant immune system is reconstituted following transplantation of autologous hematopoietic stem cells. $^{8}$ There has not yet been a randomized controlled trial of AHSCT in CIDP. The literature has consisted mostly of individual case reports or small case series, ${ }^{9-17}$ until the recent publication of an open-label single-center prospective cohort of 66 patients. ${ }^{18} \mathrm{We}$ report here our experience of AHSCT in the management of five treatment-refractory CIDP patients, including two cases of the multifocal variant known as the Lewis Sumner syndrome (LSS).

\section{Methods}

We reviewed the AHSCT database at The Ottawa Hospital to identify all cases with a primary indication of neuromuscular disease. We performed a retrospective data collection limited to cases fulfilling probable or definite EFNS/PNS diagnostic criteria for CIDP. ${ }^{19}$ Our institution permits the publication of anonymized small retrospective case series without formal REB review. Baseline patient characteristics and electrodiagnostic study results were collected. Disability before and after AHSCT was measured using the Overall Neuropathy Limitation Scale (ONLS), which is a $0-12$ ordinal scale measuring activity limitations. ${ }^{20,21}$ Neurological impairment was measured using the Medical Research Council (MRC) sum score. ${ }^{20}$ The "before" ratings refer to the 3-month period prior to AHSCT, and the "after" was the latest available data. We documented details of individual AHSCT regimens and any treatment-related adverse events. In addition to oral immunomodulatory medication regimens required to control CIDP, we specifically charted the total requirement for intravenous immunoglobulin (IVIG), in the years preceding and following AHSCT. IVIG use was expressed in total gram/year. Motor nerve conduction study results were tabulated for the median, ulnar and deep fibular nerves. Sum scores were calculated for distal motor latency, negative-peak compound muscle action amplitude and motor conduction velocity. Mean sum score values before and after transplantation were compared with a paired $t$ test.

\section{ReSUlts}

\section{Patients}

A total of five patients with refractory CIDP were treated with AHSCT in our center between 2008 and 2020. The relevant clinical and laboratory data for this cohort is summarized in Table 1. Our patient population consisted of three patients with typical, symmetrical sensorimotor CIDP and two patients with the LSS variant of CIDP. The mean age at diagnosis was 33.4 years. All patients had a predominantly relapsing- remitting course except for patient 2 who followed a slowly progressive pattern. There was no evidence of associated hematologic disorder such as monoclonal gammopathy or POEMS syndrome. Four of five patients had elevated CSF total protein (range $0.92-1.78 \mathrm{~g} / \mathrm{L}$ ) at the time of diagnostic work-up; only one patient had a mild pleocytosis (WBC count of 35). Contactin-1 and Neurofascin-155 antibodies were tested in only one patient (negative).

Prior to AHSCT, all patients had failed to achieve satisfactory sustained responses with standard CIDP therapies. All had been tried on regimens combining steroids and at least one prolonged course of IVIG or plasmapheresis. Three patients were requiring weekly dosing of IVIG to prevent severe disability and avoid prolonged hospitalization. All patients had received additional unsuccessful trials of immunosuppressive medications, including: cyclophosphamide, azathioprine, mycophenolate mofetil, cladribine and rituximab. Patient 4 had only brief exposures to immunosuppressive medication because of neutropenia and clinical side effects.

\section{AHSCT Protocols}

Peripheral blood stem cells were collected by leukapheresis after mobilization with cyclophosphamide $(2.5 \mathrm{~g} / \mathrm{m} 2)$ and granulocyte colony-stimulating factor $(10 \mathrm{mcg} / \mathrm{kg} / \mathrm{daily}$ for 10 days. Patient 1 failed to mobilize, and a bone marrow graft was collected. Immune cells were removed from the peripheral blood stem cell grafts by CD34 selection (CliniMacs, Miltenyi Biotech) prior to cryopreservation. Two patients $(\# 1,3)$ received conditioning with BEAM (Carmustine, Etoposide, Cytarabine and Melphalan) chemotherapy and rabbit anti-thymocyte globulin (Thymoglobulin, $5 \mathrm{mg} / \mathrm{kg}$ ), while the three others received conditioning with high dose cyclophosphamide (200 mg/kg), busulfan $(9.6 \mathrm{mg} / \mathrm{kg}$ ) and rabbit anti-thymocyte globulin (Thymoglobulin, $5 \mathrm{mg} / \mathrm{kg}$ ) followed by the re-infusion of the thawed autologous grafts.

\section{Adverse Reactions}

Patients were hospitalized for a period ranging from 21 to 37 days for AHSCT. Inpatient complications included febrile neutropenia in four patients, nausea and enteral feeding in one patient, mucositis in two patients (grade 2 and 3 ) and difficile enterocolitis in one patient. Infectious complications also included E. coli (one patient) and streptococcus viridans bacteremia (one patient). One patient required antibiotic and surgical management of a rectal abscess. CMV reactivation occurred in one patient, and hypogonadism was diagnosed and treated in two patients. One patient developed transient monophasic post-viral idiopathic thrombocytopenic purpura 1 year following transplant. All AHSCT complications resolved with therapy. There were no ICU admissions or 


\section{Table 1. Clinical and Laboratory documentation}

\begin{tabular}{|c|c|c|c|c|c|c|c|c|c|}
\hline Pt \# & Sex & $\begin{array}{c}\text { Age at } \\
\text { diagnosis } \\
\text { (years) }\end{array}$ & $\begin{array}{l}\text { CIDP } \\
\text { Category }\end{array}$ & CSF profile & $\begin{array}{c}\text { Time from } \\
\text { diagnosis to } \\
\text { AHSCT (months) }\end{array}$ & $\begin{array}{l}\text { CIDP therapy prior to AHSCT } \\
\text { (maximum dose) }\end{array}$ & Therapy at time of AHSCT & $\begin{array}{l}\text { Follow up post } \\
\text { AHSCT (months) }\end{array}$ & $\begin{array}{l}\text { Immunotherapy } \\
\text { at last follow-up }\end{array}$ \\
\hline 1 & M & 46 & Typical CIDP & Protein : $1.10 \mathrm{~g} / \mathrm{L}$ WBC 0 & 30 & $\begin{array}{l}\text { Pred }(50 \mathrm{mg} / \mathrm{d}), \text { PE }(\text { every week }) \text {, } \\
\text { IVIG }(2 \mathrm{~g} / \mathrm{kg} \text { every week), } \\
\text { Cycloph. }(1 \mathrm{~g} \times 7 \text { cycles }), \\
\text { Cladribine }(0.0875 \mathrm{mg} / \mathrm{kg} / \mathrm{d} \times \\
4 \text { days } \times 3 \text { cycles })\end{array}$ & $\begin{array}{l}\text { PE (every week) IVIG (150 g } \\
\text { every week), }\end{array}$ & 73 & Nil \\
\hline 2 & $\mathrm{~F}$ & 24 & Typical CIDP & Protein : $1.78 \mathrm{~g} / \mathrm{L}$ WBC 3 & 135 & $\begin{array}{l}\text { Pred }(60 \mathrm{mg} / \mathrm{d}), \text { IVIG }(1 \mathrm{~g} / \mathrm{kg} \\
\text { every } 2 \text { week }), \text { AZT }(100 \mathrm{mg} / \mathrm{d}) \text {, } \\
\text { MMF }(1 \mathrm{~g} \text { twice daily }), \\
\text { Solumedrol }(400 \mathrm{mg} \text { every } \\
\text { week }), \text { Cladribine }(0.0875 \\
\mathrm{mg} / \mathrm{kg} / \mathrm{d} \times 4 \text { days } \times 3 \text { cycles })\end{array}$ & $\begin{array}{l}\text { Pred }(10 \mathrm{mg} / \mathrm{d}), \text { IVIG (60 g every } \\
2 \text { week) }\end{array}$ & 32 & $\begin{array}{l}\text { Hydrocortisone (20 } \\
\text { mg AM-10 mg } \\
\text { PM) }\end{array}$ \\
\hline 3 & $\mathrm{M}$ & 39 & LSS & protein : $1.10 \mathrm{~g} / \mathrm{L}$ WBC 0 & 21 & $\begin{array}{l}\text { Pred }(60 \mathrm{mg} / \mathrm{d}), \text { IVIG }(1 \mathrm{~g} / \mathrm{kg} \\
\text { every week), Cycloph. } \\
(1.65 \mathrm{~g} \times 6 \text { cycles), PE (acute } \\
\text { exacerbations) }\end{array}$ & $\begin{array}{l}\text { Pred }(20 \mathrm{mg} / \mathrm{d}), \text { IVIG }(85 \mathrm{~g} \text { every } \\
\text { week) }\end{array}$ & 11 & Nil \\
\hline 4 & $\mathrm{M}$ & 31 & LSS & Protein: $0.43 \mathrm{~g} / \mathrm{L}$ WBC 0 & 46 & $\begin{array}{l}\text { Pred }(60 \mathrm{mg} / \mathrm{d}), \text { IVIG }(1 \mathrm{~g} / \mathrm{kg} \\
\text { every } 2 \text { week), short trials of } \\
\text { AZT (neutropenia) and MMF } \\
\text { (cramps and insomnia) }\end{array}$ & IVIG ( $80 \mathrm{~g}$ every 2 week) & 41 & Nil \\
\hline 5 & $\mathrm{M}$ & 27 & Typical CIDP & Protein: $0.92 \mathrm{~g} / \mathrm{L}$ WBC 35 & 56 & $\begin{array}{l}\text { Pred }(100 \mathrm{mg} / \mathrm{d}), \text { IVIG }(1 \mathrm{~g} / \mathrm{kg} \\
\text { every } 3 \text { week), short trial of } \\
\text { mycophenolate mofetil } \\
\text { (6 weeks), Cycloph. }(250 \mathrm{mg} / \mathrm{d})\end{array}$ & IVIG (100 g every 3 week) & 119 & Nil \\
\hline
\end{tabular}

Abbreviations: AHSCT = autologous hematopoietic stem cell transplantation; AZT = azathioprine; CIDP = chronic inflammatory demyelinating polyneuropathy; Cycloph = cyclophosphamide; Dexa = dexamethasone; IVIG = intravenous immunoglobulin therapy; LSS $=$ Lewis Sumner syndrome; MMF $=$ mycophenolate mofetil Nil $=$ absence of CIDP-specific therapy; PE = plasma exchange; Pred = prednisone; $\mathrm{Pt}=$ Patient; $\mathrm{WBC}=$ white blood cell. 
Table 2. Laboratory course following transplantation

\begin{tabular}{|c|c|c|c|c|c|c|}
\hline Patient \# & Conditioning regimen & Graft source & $\begin{array}{l}\text { CD } 34 \text { cells infused } \\
\left(10^{6} \text { cells } / \mathrm{kg}\right)\end{array}$ & $\begin{array}{c}\text { Time to } \\
\text { ANC }>0.5 \times 10^{9} / \mathrm{L} \\
(\text { days post } \mathrm{HSCT})\end{array}$ & $\begin{array}{c}\text { Time to platelet count } \\
>20 \times 10^{9} / L(\text { days post } \\
\text { HSCT })\end{array}$ & $\begin{array}{l}\text { Transplant admission } \\
\text { duration (\# of } \\
\text { inpatient days) }\end{array}$ \\
\hline 1 & BEAM/ATG & PBSC + BM & 2.15 & 11 & 23 & 37 \\
\hline 2 & $\mathrm{Bu} / \mathrm{Cy} / \mathrm{ATG}$ & CD34 selected PBSC & 4.33 & 9 & 12 & 26 \\
\hline 3 & BEAM/ATG & CD34 selected PBSC & 4.96 & 13 & 24 & 32 \\
\hline 4 & $\mathrm{Bu} / \mathrm{Cy} / \mathrm{ATG}$ & CD34 selected PBSC & 13.05 & 13 & 14 & 29 \\
\hline 5 & $\mathrm{Bu} / \mathrm{Cy} / \mathrm{ATG}$ & CD34 selected PBSC & 1.99 & 11 & 10 & 21 \\
\hline
\end{tabular}

Abbreviations: $\mathrm{ANC}=$ absolute neutrophil count; ATG = anti-thymocyte globulin; BEAM = Carmustine, Etoposide, Cytarabine and Melphalan; $\mathrm{BM}=$ bone marrow $\mathrm{Bu}=$ Busulphan; $\mathrm{Cy}=$ cyclophosphamide; $\mathrm{HSCT}=$ hematopoietic stem cell transplantation; PBSC $=$ peripheral blood stem cell.

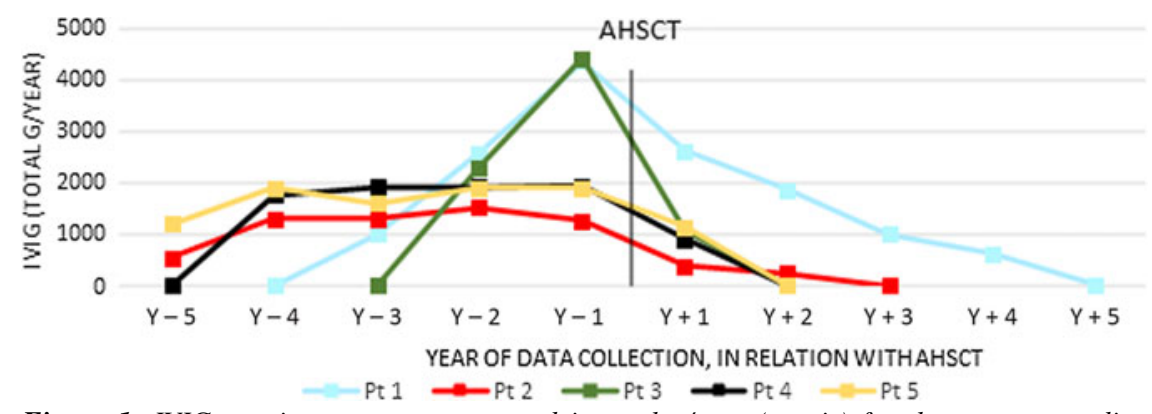

Figure 1. IVIG requirements are expressed in total g/year (y axis) for the years preceding $(Y-1, Y-2 \ldots)$ and following $(Y+1, Y+2)$ autologous hematopoietic stem cell transplantation (AHSCT).

critical illness events. Relevant laboratory documentation of the AHSCT treatment course is summarized in Table 2.

\section{Clinical Response}

Patients were followed for a median period of 41 months after AHSCT (range 11-119 months). All patients were able to wean off immunosuppressive therapy following transplant. Patient 2 required long term hydrocortisone replacement therapy. She had developed persistent adrenal insufficiency following a 14-year steroid treatment course. IVIG dose requirements for all five patients in the peri-transplant period have been plotted in Figure 1, demonstrating a sharp reduction in IVIG requirements. In the first year following AHSCT, most received monthly low dose IVIG $(0.5 \mathrm{mg} / \mathrm{kg})$ for infection prophylaxis, as per our institutional protocol. One patient continued to experience disabling exacerbations of CIDP in the first 6 months post AHSCT and required ongoing high-dose IVIG and therapeutic plasma exchange for a period of 16 months; by 24 months post AHSCT he had achieved a sustained treatment-free clinical remission.

Clinical improvements peri-transplant have been plotted in Figure 2, using the MRC sum score and ONLS disability scale. Four patients have so far achieved complete sustained clinical remission following transplant and were able to resume all normal professional and personal activities. Patient 2 failed to demonstrate clinical improvement but was able to maintain stability without IVIG treatment and was able to return to parttime work.

Most post-transplant nerve conduction studies showed trends towards improved electrodiagnostic parameters, such as lower distal
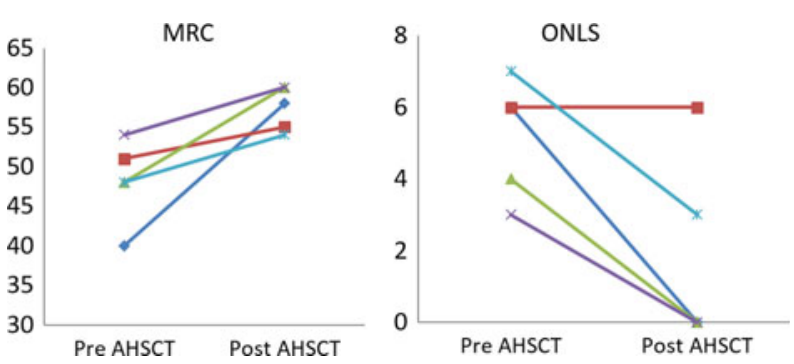

Figure 2. A greater MRC sum score or lower ONLS correlate with improved clinical status.

Abbreviations: AHSCT, autologous hematopoietic stem cell transplantation; MRC, medical research council; ONLS, Overall Neuropathy Limitations Scale.

motor latencies and higher motor conduction velocities and compound muscle action potential amplitudes. One notable exception was patient 2 , who had a decade long pre-transplant course with marked distal axonal loss. The sample size was however too small to expect such trends to reach statistical significance - paired $t$-test showed no significant difference between the pre and post transplantation mean conduction sum scores.

\section{DiscuSSION}

This case series provides uncontrolled evidence suggesting possible efficacy of AHSCT in patients with treatment refractory CIDP. Our five patients have so far maintained clinical stability without a need for ongoing CIDP-related immunotherapy. Four of five patients showed improvements in muscle strength post- 
transplant (as demonstrated by increased MRC scores) and lessening of disability by a minimum of three points on the ONLS scale. One patient did not show clinical improvement, likely because of chronic axonal loss after a disease progression of more than a decade. This demonstrates the importance of achieving a prompt diagnosis and treatment of CIDP, to avoid cumulative secondary axonal loss which reduces the likelihood of clinical recovery. ${ }^{22-24}$ Our series also includes two patients with a severe LSS, for which the option of AHSCT has been even less well documented in the literature. ${ }^{16,18}$

The first report of AHSCT in CIDP was by Vermeulen and Van Oers in 2002. ${ }^{9}$ Their patient had a 10-year history of treatment refractory CIDP. He was treated with AHSCT using a BEAM conditioning protocol. He showed a sustained clinical response for 5 years but subsequently required immunosuppressive therapy for a relapse. ${ }^{10}$

Most early publications on AHSCT in CIDP were brief case reports of 1-2 patients ${ }^{9,11-13,15}$ with an additional more substantial case series summarizing the experience from four Swedish university hospitals. ${ }^{14}$ This 11 -subject series provided the earliest consistent longitudinal data on the assessment of disability and clinical outcome. ${ }^{14}$ There were highly statistically significant reductions in both INCAT scores (reduction of median values from 6 to 1) and Rankin scores (reduction of median value from 4 to 1 ). Overall there was suggestive but anecdotal evidence of meaningful clinical benefit in early publications, typically with improvement from wheelchair to independent ambulation within 1 year of institution of AHSCT. A much larger cohort of 66 cases of CIDP was recently reported from an FDA-approved phase I/II trial of AHSCT conducted at the Northwestern Memorial Hospital (Chicago, IL). ${ }^{18}$ Six patients were either lost to follow-up, found to have POEMS, or died from unrelated causes. Remission, defined as stable or improving clinical status without immunotherapy, was noted in $80 \%$ at 1 year and $83 \%$ at 5 years. Comparing results for before with all timepoints after transplantation, there were statiscically significant reductions in MRC and INCAT scores as well as improvements in grip strength and quality of life measured with the SF-36 physical, mental and total scores.

Relapse of CIDP after initially successful AHSCT is however also well documented. In a review of literature up to 2018 , 8 of 21 patients reported to have had relapses, mostly within 2 years, at a median interval of 16 months (range 1-60 months). ${ }^{8}$ One of these patients even received a second successful course of AHSCT. In the Northwestern Memorial Hospital series, $18 \%$ of patients had restarted some form of immune-based therapy for CIDP within the 5-year follow-up period. The literature is too heterogenous to conclude if relapses correlate with patient selection characteristics or variations in the AHSCT mobilization and conditioning protocols.

There was a single case of AHSCT for LSS in older literature. ${ }^{16}$ This 24 -year-old male with a 12 -year history of refractory multifocal CIDP showed transient recovery of muscle weakness and resolution of conduction blocks. However, at 2 months' follow-up post AHSCT his neurological and electrophysiological status had returned to the pretreatment baseline. The Northwestern Memorial Hospital series included four successfully treated LSS cases. ${ }^{18}$ This is similar to our experience with two cases of LSS maintaining complete remission at 11 and 41 months post transplantation.

AHSCT does expose patients to significant risks of marked transient bone marrow suppression and systemic toxicity. ${ }^{25}$ Patients with CIDP would be expected to suffer from similar acute and late complications of AHSCT reported for patients with other autoimmune and malignant disease. With modernday conditioning regimens and careful monitoring, mortality rates for AHSCT in autoimmune diseases are typically less than the $3 \%-4 \%$ range. $^{26,27}$ No mortality has so far been reported for the treatment of CIDP with bone marrow transplantation, but the numbers treated remain too small to reflect such low probability occurrences. The intense chemotherapy administered prior to AHSCT increases the long-term risk of post-transplant malignancy. ${ }^{28}$ The more frequent potential late effect of AHSCT is autoimmune disease (typically thyroid or hematologic). There is a cumulative risk in the range of $9.8 \%$ at 5 years for developing a second autoimmune disorder when AHSCT was performed for an autoimmune indication, rather than for treatment of malignancy. ${ }^{29}$ Risks of AHSCT must however be weighed against the long-term cumulative risks and costs of immunotherapy maintained for decades in patients with CIDP. Additionally, persistent neuropathic disability may impair quality of life and occupational productivity. For at least four of our patients, AHSCT has so far provided a complete and sustained medication-free neurologic remission.

The clinical course of patient 1 raises interesting questions about the time-course and mechanism of the immunologic response to AHSCT in the context of CIDP. There was a triphasic response: immediate brief remission, return of active disabling inflammatory neuropathy requiring resumption of baseline immunotherapy, and subsequent gradual remission of CIDP to a treatment-free state. One can postulate that the initial response was mediated by the lymphopenia resulting from the transplant conditioning. The return of active CIDP may have reflected a homeostatic expansion of graft lymphocytes as this patient did not receive a CD34 selected graft.

Several limitations of our retrospective cohort must be acknowledged. As the initial diagnostic workup for most patients took place several years ago, neurofascin-155/Contactin-1 antibody levels were tested in only one patient. These antibodies should now be systematically sought in the assessment of treatment-refractory $\mathrm{CIDP}^{30,31}$ and they may point to different treatment strategies, including the option of an early trial of rituximab. Only one of our patients was offered a trial of rituximab prior to AHSCT. Rituximab has limited evidence for efficacy in refractory CIDP, ${ }^{32-34}$ but at our institution access was limited by provincial health authority coverage limitations. As there is a significant possibility that biologic agents will be increasingly shown to benefit CIDP patients, it may be preferable that such treatments be made more widely available to patients before considering AHSCT. The MRC sum score and ONLS assessment scales (chosen because they could be uniformly applied to a cohort dating back to 2008) may not be as reliable as modern scales such as the Rasch-built Overall Disability Scale for Immune Neuropathy. Finally, the small size of our cohort did not allow for meaningful assessments of electrodiagnostic data as an additional surrogate measure of treatment response. 
Although a controlled clinical trial of AHSCT in CIDP (similar to what has been reported in multiple sclerosis ${ }^{6}$ ) would be desirable, the rarity of this condition, particularly if selecting treatment-refractory cases, would pose considerable logistic challenges. Our report adds to the accumulating empirical evidence suggesting AHSCT can induce sustained remission. It may also be postulated that in carefully selected cases the risk of a very intense but time-limited immunosuppression (AHSCT) may compare favorably to the protracted cumulative side-effects, massive economic costs, and lifestyle restrictions associated with decades of immunotherapy.

\section{Disclosures}

The authors report no relevant disclosures.

\section{Statement of Authorship}

$\mathrm{AM}-\mathrm{R}, \mathrm{PB}, \mathrm{AB}$ and $\mathrm{HA}$ performed statistical analysis, wrote and revised the manuscript. DA, CB, LH, NK, MLK, LM,SM and $\mathrm{SA}$ were involved in data acquisition and manuscript revision. JW and CEP were involved in study design, interpretation and manuscript revision.

\section{REFERENCES}

1. Cocito D, Paolasso I, Antonini G, et al. A nationwide retrospective analysis on the effect of immune therapies in patients with chronic inflammatory demyelinating polyradiculoneuropathy. Eur J Neurol. 2010;17:289-94.

2. Gorson KC, Allam G, Ropper AH. Chronic inflammatory demyelinating polyneuropathy: clinical features and response to treatment in 67 consecutive patients with and without a monoclonal gammopathy. Neurology. 1997;48:321-28.

3. Gorson KC, van Schaik IN, Merkies IS, et al. Chronic inflammatory demyelinating polyneuropathy disease activity status: recom mendations for clinical research standards and use in clinical practice. J Peripher Nerv Syst. 2010;15:326-33.

4. Mahdi-Rogers M, Brassington R, Gunn AA, van Doorn PA, Hughes RA. Immunomodulatory treatment other than corticosteroids, immunoglobulin and plasma exchange for chronic inflammatory demyelinating polyradiculoneuropathy. Cochrane Database Syst Rev. 2017;5:CD003280.

5. Sharrack B, Saccardi R, Alexander T, et al. Autologous haematopoietic stem cell transplantation and other cellular therapy in multiple sclerosis and immune-mediated neurological diseases: updated guidelines and recommendations from the EBMT Autoimmune Diseases Working Party (ADWP) and the Joint Accreditation Committee of EBMT and ISCT (JACIE). Bone Marrow Transplant. 2019:10.1038/s41409-41019-40684-41400.

6. Muraro PA, Pasquini M, Atkins HL, et al. Long-term outcomes after autologous hematopoietic stem cell transplantation for multiple sclerosis. JAMA Neurol. 2017;74:459-69.

7. Bryant A, Atkins H, Pringle CE, et al. Myasthenia Gravis treated with autologous hematopoietic stem cell transplantation. JAMA Neurol. 2016;73:652-58.

8. Burman J, Tolf A, Hägglund H, Askmark H. Autologous haematopoietic stem cell transplantation for neurological diseases. J Neurol Neurosurg Psychiatry. 2018;89:147-55.

9. Vermeulen M, Van Oers MH. Successful autologous stem cell transplantation in a patient with chronic inflammatory demyelinating polyneuropathy. J Neurol Neurosurg Psychiatry. 2002;72:127-28.

10. Vermeulen M, van Oers MH. Relapse of chronic inflammatory demyelinating polyneuropathy 5 years after autologous stem cell transplantation. J Neurol Neurosurg Psychiatry. 2007;78:1154.

11. Bregante S, Gualandi F, van Lint MT, Schenone A, Bacigalupo A, Marmont AM. Sjogren's syndrome associated chronic inflammatory demyelinating polyradiculoneuropathy (CIDP) treated with autologous and subsequently allogeneic haematopoietic SCT (HSCT). Bone Marrow Transplant. 2013;48:1139-40.

12. Mahdi-Rogers M, Kazmi M, Ferner R, et al. Autologous peripheral blood stem cell transplantation for chronic acquired demyelinating neuropathy. J Peripher Nerv Syst. 2009;14: $118-24$.

13. Oyama Y, Sufit R, Loh Y, et al. Nonmyeloablative autologous hematopoietic stem cell transplantation for refractory CIDP. Neurology. 2007;69:1802-803.

14. Press R, Askmark H, Svenningsson A, et al. Autologous haematopoietic stem cell transplantation: a viable treatment option for CIDP. J Neurol Neurosurg Psychiatry. 2014;85:618-24.

15. Axelson HW, Oberg G, Askmark H. Successful repeated treatment with high dose cyclophosphamide and autologous blood stem cell transplantation in CIDP. BMJ Case Rep. 2009;2009: bcr09.2008.0927.

16. Barreira AA, Mestriner Júnior W, Ramos JO, et al. Non-myeloblative autologous hematopoietic stem cell transplantation for chronic inflammatory demyelinating neuropathy (CIDP). Neurology. 2010;74:A527-A528.

17. Kamat A, Elston T, Tueger S, et al. Autologous peripheral blood progenitor cell transplantation in refractory chronic inflammatory demyelinating polyradiculopathy. Bone Marrow Transplant. 2006;37:S132.

18. Burt RK, Balabanov R, Tavee J, et al. Hematopoietic stem cell transplantation for chronic inflammatory demyelinating polyradiculoneuropathy. J Neurol. 2020;267:3378-91.

19. Joint Task Force of the E, the PNS. European Federation of Neurological Societies/Peripheral Nerve Society Guideline on management of chronic inflammatory demyelinating polyradiculoneuropathy: report of a joint task force of the European Federation of Neurological Societies and the Peripheral Nerve Society-First Revision. J Peripher Nerv Syst. 2010; 15:1-9.

20. Graham RC, Hughes RAC. A modified peripheral neuropathy scale: the overall neuropathy limitations scale. J Neurol Neurosurg Psychiatry. 2006;77:973-76.

21. Merkies IS, Schmitz PI, van der Meché FG, Samijn JP, van Doorn PA. Connecting impairment, disability, and handicap in immune mediated polyneuropathies. J Neurol Neurosurg Psychiatry. 2003;74:99-104.

22. Kuwabara S, Misawa S, Mori M, Tamura N, Kubota M, Hattori T. Long term prognosis of chronic inflammatory demyelinating polyneuropathy: a five year follow up of 38 cases. J Neurol Neurosurg Psychiatry. 2006;77:66-70.

23. Bouchard C, Lacroix C, Planté V, et al. Clinicopathologic findings and prognosis of chronic inflammatory demyelinating polyneuropathy. Neurology. 1999;52:498-503.

24. Rabin M, Mutlu G, Stojkovic T, et al. Chronic inflammatory demyelinating polyradiculoneuropathy: search for factors associated with treatment dependence or successful withdrawal. J Neurol Neurosurg Psychiatry. 2014;85:901-906.

25. Daikeler T, Tichelli A, Passweg J. Complications of autologous hematopoietic stem cell transplantation for patients with autoimmune diseases. Pediatr Res. 2012;71:439-44.

26. Farge D, Labopin M, Tyndall A, et al. Autologous hematopoietic stem cell transplantation for autoimmune diseases: an observational study on 12 years' experience from the European Group for Blood and Marrow Transplantation Working Party on Autoimmune Diseases. Haematologica. 2010;95:284-92.

27. Atkins HL, Freedman MS. Hematopoietic stem cell therapy for multiple sclerosis: top 10 lessons learned. Neurotherapeutics. 2013;10:68-76.

28. Inamoto Y, Shah NN, Savani BN, et al. Secondary solid cancer screening following hematopoietic cell transplantation. Bone Marrow Transplant. 2015;50:1013-23.

29. Daikeler T, Labopin M, Di Gioia M, et al. Secondary autoimmune diseases occurring after HSCT for an autoimmune disease: a retrospective study of the EBMT Autoimmune Disease Working Party. Blood. 2011;118:1693-98.

30. Querol L, Nogales-Gadea G, Rojas-Garcia R, et al. Antibodies to contactin-1 in chronic inflammatory demyelinating polyneuropathy. Ann Neurol. 2013;73:370-80. 
31. Querol L, Nogales-Gadea G, Rojas-Garcia R, et al. Neurofascin IgG4 antibodies in CIDP associate with disabling tremor and poor response to IVIg. Neurology. 2014;82:879-86.

32. Benedetti L, Briani C, Franciotta D, et al. Rituximab in patients with chronic inflammatory demyelinating polyradiculoneuropathy: a report of 13 cases and review of the literature. J Neurol Neurosurg Psychiatry. 2011;82:306-308.
33. Querol L, Rojas-García R, Diaz-Manera J, et al. Rituximab in treatment-resistant CIDP with antibodies against paranodal proteins. Neurol Neuroimmunol Neuroinflamm. 2015;2: e149.

34. Muley SA, Jacobsen B, Parry G, et al. Rituximab in refractory chronic inflammatory demyelinating polyneuropathy. Muscle Nerve. 2020;61:575-79. 